\title{
Peningkatan Pengetahuan Khasiat Parutan Kunyit Dan Madu Untuk Meredakan Nyeri Disminore Pada Sisiwi Di Sma Pesantren Pancasila Kota Bengkulu Tahun 2020
}

\author{
Lezi Yovita Sari, Yesi Putri, Taufianie Rossita, Syami Yulianti, Desi Aulia Umami \\ Program Studi Sarjana Kebidanan, Fakultas IImu Kesehatan, Universitas Dehasen Bengkulu \\ Leziyovitas@gmail.com
}

\begin{abstract}
Abstrak
Disminore adalah nyeri saat haid rasa kram dan terpusat di abdomen bawah serta nyeri pinggang. Disminore dapat terjadi i mulai dari yang ringan sampai yang berat.Minuman kunyit adalah minuman yang diolah dengan bahan utama kunyit.secara alamiah memang kunyit dipercaya memiliki kandungan bahan aktif yang dapat berfungsi sebagai analgetik, antipiretika, antiinflamasi. Selain itu, dijelaskan bahwa minuman kunyit sebagai pengurang rasa nyeri pada disminore primer. Madu merupakan salah satu bahan herbal dan nutrisi alami yang efek sampingnya minimal, rasa yang enak dan harga yang relative terjangkau. Madu mengandung anti mikroba dan anti inflamasi karena madu memiliki enzim, mineral, yang efektif menurunkan nyeri seperti nyeri haid, nyeri pinggang, sakit kepala, dan lain-lain. Gunakan madu sebanyak 1 sendok teh kemudian beri air sebanyak setengah gelas kecil, setelah madu dan kunyit tercampur silahkan minum $2 x$ sehari. Berdasarkan hasil bahwa tingkat pengetahuan remaja tentang khasiat parutan kunyit dan madu untuk meredakan nyeri disminorea, kategori pengetahuan Baik Sebanyak 5 responden (23\%), pada kategori pengetahuan kurang sebanyak 17 Responden (77\%). dapat disimpulkan bahwa remaja yang pengetahuan tinggi tentang khasiat parutan kunyit dan madu untuk meredakan nyeri disminorea yang terbanyak adalah dalam kategori pengetahuan kurang baik yaitu sebanyak 17 responden (77\%). Dalam hal ini masih sangat perlu di tingkatkan untuk memberikan pendidikan kesehatan tentang bagaimana meredakan nyeri disminorea dengan khasiat parutan kunyit dan madu terhadap remaja putri.
\end{abstract}

Kata kunci : Nyeri Disminore, Remaja Putri

\begin{abstract}
Abstrack
Dysminorrhea is painful during menstrual cramps and is concentrated in the lower abdomen and low back pain. Dysminorrhea can occur starting from mild to severe. Turmeric drink is a beverage that is processed with the main ingredients of turmeric. Naturally, turmeric is believed to contain active ingredients that can function as analgesic, antipyretic, antiinflammatory. In addition, it was explained that turmeric drinks as a pain reliever in primary dysminore. Honey is one of the herbal ingredients and natural nutrients with minimal side effects, good taste and relatively affordable prices. Honey contains anti-microbial and antiinflammatory because honey has enzymes, minerals, which are effective in reducing pain such as menstrual pain, low back pain, headaches, and others. Use as much as 1 teaspoon of honey then give as much as half a small glass of water, after honey and turmeric are mixed please drink $2 x$ a day. Based on the results that the level of knowledge of adolescents about the efficacy of grated turmeric and honey to relieve disminorea pain, the category of knowledge http://ejournal.urindo.ac.id/index.php/PAMAS
\end{abstract}


Good As many as 5 respondents (23\%), in the category of knowledge lacking as many as 17 respondents (77\%). it can be concluded that adolescents who have high knowledge about the efficacy of grated turmeric and honey to relieve the pain of disminorea most are in the category of poor knowledge as many as 17 respondents (77\%). In this case it still needs to be improved to provide health education about how to relieve the pain of disminorea with the efficacy of grated turmeric and honey for young women.

Keywords: Disminore Pain, Young Women

\section{PENDAHULUAN}

Menstruasi adalah situasi pelepasan endometrium dalam bentuk serpihan dan pendarahan akibat pengeluaran hormon estrogen dan progesterone yang turun dan berhenti sehingga terjadi vasokontraksi pembuluh darah yang segera diikuti vasodilatasi. Mentruasi merupakan petunjuk pertama bahwa mekanisme wanita telah matang, yang ditunjukan dengan datangnya serangkaian pengeluaran darah, lendir dan jaringan sel yang hancur dari uterus secara berkala yang akan terjadi kira-kira 28 hari tiap bulannya hingga mencapai menopouse. Pada saat menstruasi,darah keluar akibat peluruhan dinding rahim (endometrium). Darah menstruasi akan mengalir dari rahim menuju keleher rahim yang kemudian keluar melalui vagina (Sunarko, 2015).

Nyeri haid atau Disminore adalah nyeri saat haid, biasanya dengan rasa kram dan terpusat di abdomen bawah serta nyeri pinggang. Disminore dapat terjadi bervariasi mulai dari yang ringan sampai yang berat (Kusmiran, 2012).

Angka kejadian nyeri menstruasi di seluruh dunia masih sangat banyak, persentase kejadian nyeri menstruasi di dunia rata-rata lebih dari 50\% atau berkisar sebesar 15,8-89,5\% wanita di setiap negara mengalami nyeri menstruasi. Prevalensi nyeri menstruasi di Amerika Serikat diperkirakan sebesar 45-90\%, kemudian di India adalah sebesar 75\% dan di Mesir angka prevalensinya telah diperkirakan sebesar 75\% (American Family Physician, 2014).

Angka kejadian nyeri menstruasi primer di Indonesia mencapai 54,89\%, sedangkan sisanya adalah penderita tipe sekunder, yang menyebabkan mereka tidak mampu melakukan kegiatan apapun dan ini akan menurunkan kualitas hidup pada individu masing-masing (Proverawati \& Misaroh, 2012).

Disminore terjadi karena peningkatan prostaglandin (PG) F2-alfa yang mengakibatkan suatu siklooksigenase (COX-2) yang mengakibatkan hipertonus dan vasokontraksi pada myometrium sehingga iskemia dan nyeri haid. Selain itu juga terdapat PGE2 alfa yang turu 
serta menyebabkan disminore primer. Disminore yang sering terjadi pada remaja disminore primer. Disminore primer adalah suatu nyeri haid yang tidak terdapat hubungan dengan kelainan ginekologik. Remaja putri akan lebih sering merasakan sakit akibat disminore primer karena siklus hormonal yang dialami belum begitu stabil, dan remaja putri belum sering mengalami kontraksi uterus seperti wanita dewasa muda. Disminore primer ini akan sangat mengganggu konsentrasi dan aktivitas para remaja putri (Junizar, Suliamingsih \& Widya, 2011).

Peran bidan dalam upaya mengurangi nyeri disminore yaitu melakukan penyuluhan mengenai cara untuk mengurangi keluhan tersebut pada remaja, dengan berperilaku hidup sehat, memperbaiki keadaan kesehatan seperti perbaikan gizi, kehidupan yang sehat dan tenang, olah raga dan konsumsi nutrisi yang seimbang. Bidan bisa menganjurkan terhadap pemanfaatan obat herbal seperti parutan kunyit dan madu untuk mengurangi nyeri disminore pada remaja.

Ada beberapa cara untuk meredakan gejala-gejala disminore yaitu dengan cara farmakologi dan non farmakologi. Pengobatan yang dapat dipakai adalah dengan menggunakan agen-agen anti inflamasi nonsteroid (NSAID) yang bekerja sebagai antiprostaglandin yang dapat meredakan nyeri. Obat farmakologi yang sering digunakan adalah analgesik dan anti inflamasi seperti asam mefenamat, ibuprofen, dan lain-lain. Akan tetapi penggunaan obat farmakologi menimbulkan efek samping seperti gangguan pada lambung dan penurunan pada darah (anemia). Sedangkan pengobatan non farmakologi, banyak hal yang dilakukan untuk mengurangi rasa nyeri pada disminore primer, misalnya penggunaan kompres hangat, olahraga teratur, senam disminore, minum jamu kunyit asam, air parutan kunyit bercampur madu dan mengkonsumsi produk-produk herbal yang telah dipercaya khasiatnya (Smith, 2010).

Produk herbal atau fitofarmaka saat ini memang sedang menjadi alternatif utama bagi para remaja putri yang ingin mengurangi rasa nyeri tanpa mendapat efek samping. Salah satu produk herbal yang biasa di konsumsi dan telah familiardi masyarakat untuk mengurangi nyeri haid adalah minum kunyit. Dalam hal ini sebagian masyarakat Indonesia hanya percaya bahwa memiliki kebiasaan mengkonsumsi minuman kunyit atau yang di kenal dengan minuman kunyit asam yang dapat mengurangi keluhan disminore primer. Namun, masyarakat tidak mengetahui kandungan dari kunyit tersebut (Winarto, 2013). 
Berdasarkan hasil yang sudah dilakukan oleh peneliti lain pada mahasiswi PSIK Universitas Muhammadiyah Malang pada 15 mahasiswi angkatan 2012 yang mengalami disminore, setelah diberikan ramuan air parutan kunyit dan madu 13 orang diantara mereka mengalami perubahan pada nyeri disminore yang mereka rasakan, skala nyeri yang mereka rasakan menurun setelah mereka mengkonsumsi air parutan kunyit dan madu.

Minuman kunyit adalah suatu minuman yang diolah dengan bahan utama kunyit.secara alamiah memang kunyit dipercaya memiliki kandungan bahan aktif yang dapat berfungsi sebagai analgetik, antipiretika, antiinflamasi. Selain itu, dijelaskan bahwa minuman kunyit sebagai pengurang rasa nyeri pada disminore primer memiliki efek samping. Senyawa aktif atau bahan kimia yang terkandung dalam kunyit adalah curcumine. Kunyit yang digunakan ialah 1 ruas berukiran sedang, cuci, buang kulit pada kunyit, dan parut 1 ruas kunyit (10 gram) menggunakan parutan sampai mendapatkan air kunyit (Winarto, 2013).

Madu merupakan salah satu bahan herbal dan nutrisi alami yang efek sampingnya minimal, rasa yang enak dan harga yang relative terjangkau. Madu mengandung anti mikroba dan anti inflamasi karena madu memiliki enzim, mineral, yang efektif menurunkan nyeri seperti nyeri haid, nyeri pinggang, sakit kepala, dan lain-lain. Pengobatan herbal seperti madu juga meredakan kontraksi otot halus uterine disebabkan oleh oxytocin dan E2 prostaglandins (Mirbagher \& Aghajani, 2013). Sifat antibakteri madu membantu mengatasi infeksi pada luka, sedangkan aksi inflamasinya dapat mengatasi nyeri serta meningkatkan sirkulasi (Sakri, 2015). Gunakan madu sebanyak 1 sendok teh kemudian beri air sebanyak setengah gelas kecil, setelah madu dan kunyit tercampur silahkan minum sebanyak $2 x$ sehari.

\section{METODE}

Metode dalam pengabdian ini menggunakan cerama, diskusi dan Tanya jawab. Materi yang akan dii sampaikan tentang khasiat parutan kunyit dan madu dalam meredahkan nyeri disminore. pengabdian yang kami lakukan yaitu membagikan koesiner untuk mengukur pengetahuan siswi tentang khasiat parutan kunyit dan madu dalam meredahkan nyeri pada dismonore, kemudian kami memberikan penyuluhan dalam bentuk cerama, diskusi dan Tanya jawab.

\section{Keterkaitan Kegiatan}


Kegiatan pengabdian masyarakat ini dilaksanakan di SMA Pesantren Pancasila Kota Bengkulu Provinsi Bengkulu. Kegiatan ini sebagai suatu kegiatan yang menambah pengetahuan kepada sisiwi tentang bagaimana mengurangi nyeri disminore pada saat menstruasi.

\title{
HASIL DAN PEMBAHASAN
}

\begin{abstract}
Berdasarkan hasil pengolahan data pengabdian masyarakat bahwa tingkat pengetahuan remaja tentang khasiat parutan kunyit dan madu untuk meredakan nyeri disminorea, kategori pengetahuan Baik Sebanyak 5 responden (23\%), pada kategori pengetahuan kurang sebanyak 17 Responden (77\%). dapat disimpulkan bahwa remaja yang pengetahuan tinggi tentang khasiat parutan kunyit dan madu untuk meredakan nyeri disminorea yang terbanyak adalah dalam kategori pengetahuan kurang baik yaitu sebanyak 17 responden (77\%). Dalam hal ini masih sangat perlu di tingkatkan untuk memberikan pendidikan kesehatan tentang bagaimana meredakan nyeri disminorea dengan khasiat parutan kunyit dan madu terhadap remaja putri.
\end{abstract}

Pengetahuan remaja tentang Khasiat parutan kunyit dan madu untuk meredakan nyeri disminore masih sangat rendah. Pengetahuan merupakan hasil dari tahu dan ini terjadi setelah orang melakukan pengindraan terhadap suatu obyek tertentu. Pengindraan terjadi melalui pancaindra manusia yakni indra penglihatan, pendengaran, penciuman, rasa dan raba. Sebagian besar pengetahuan manusia diperoleh melalui mata dan telinga. Pengetahuan berperan besar dalam memberikan wawasan terhadap pembentukan sikap masyarakat terhadap kesehatan. Sikap tersebut akan diikuti dengan tindakan dalam melakukan usahausaha peningkatan kesehatan. Remaja yang tidak mempunyai pengetahuan yang luas tentang bagaimana cara meredahkan nyeri disminorea sehingga masih banyak siswi yang mengkonsumsi obat-obat kimia dan masih banyak yang membiarkan nyeri desminorea berhenti dengan sendirinya dengan jangka waktu nyeri satu sampai dua hari sehingga tidak bisa melakukan aktivitas seperti biasanya. (Notoatmodjo, 2010).

Faktor lain yang berpengaruh terhadap pengetahuan seseorang yaitu yang berasal dari pengalaman, hubungan sosial, paparan media masa seperti majalah, televisi, dan buku (Notoatmodjo, 2012). Informasi dan pendidikan sangat berperan penting dalam tingkat pengetahuan seseorang (Mubarak, 2011).

http://ejournal.urindo.ac.id/index.php/PAMAS 
Salah satu upaya untuk menciptakan perilaku masyarakat yang kondusif untuk kesehatan melalui penyuluhan kesehatan yaitu dengan melakukan pendekatan untuk meningkatkan pengetahuan, sikap dan perilaku masyarakat tentang khasiat parutan kunyit dan madu dalam meredahkan nyeri disminore.

\section{SIMPULAN}

Pengetahuan, sangat produktif berkaitan dalam) khasiat parutan kunyit dan madu untuk meredakan nyeri disminore pada remaja putri. Selain itu pendidikan kesehatan dan peran serta tenaga kesehatan untuk mengenal dan mengajarkan pada remaja tentang bagaimana meredahkan disminorea dengan khasiat parutan kunyit dan madu, serta kemampuan menggunakan media juga memengaruhi dalam pencarian informasi aktif tentang manfaat khasiat parutan kunyit dan madu. Pengetahuan yang cukup dan pentingnya melakukan pengobatan nyeri disminore dengan dini, singga bisa meredahkan nyeri disminore dengan cepat pada awal menstruasi. Tindakan pengobatan dengan khasiat parutan kunyit dan madu sangat efektip untuk meredahkan nyeri disminore dan aman terhadap kesehatan remaja,.

\section{DAFTAR PUSTAKA}

American Family Physician. 2014. Diagnosis and Initial Management of Dysmenorrhea. Dallas, Texas: University of Texas Southwestern Medical Center.

Junizar, Sulianingsih dan widya. 2001. Pengobatan Dismenore secara Akupuntur. Jakarta: KSMF Akupuntur Rumah Sakit Umum Pusat Nasional Dr. Cipto Mangun Kusumo

Kusmiran, Eny. 2011. Kesehatan Remaja dan Wanita. Sunarko. 2015. Menarche. Yogyakarta : Nuha Medika.

Mirbagher, N \& Aghajani, M. (2013). Comparing the Effect of Pure and impure Honey on Severity of Pain, amount of Bleeding, and duration and Interval of Menstrual

Mubarak. W. I. (2011). Promosi kesehatan. Jogyakarta : Graha ilmu.

Notoatmodjo,2010. Ilmu Perilaku Kesehatan. Jakarta : Rineka Cipta

Notoatmodjo S. 2012. Promosi Kesehatan dan Perilaku Kesehatan. Jakarta: PT Rineka Cipta.

$\underline{\text { http://ejournal.urindo.ac.id/index.php/PAMAS }}$ 
Jurnal Pelayanan dan Pengabdian Masyarakat

Proverawati, Misaroh. 2012. Menarche: Menstruasi Pertama Penuh Makna. Yogyakarta : Nuha Medika

Sakri, Faisal. 2015. Madu dan Khasiatnya. Yogyakarta : Diandra Bina Pustaka

Smith R.P. 2010. Dysmenorrhea: Etiology, Diagnosis, and Therapy. Tersedia dalam: http://www.womenshealthapta.org/csm2003/4654.pdf. Diakses tanggal 4 Mei 2019

Winarto. 2013. Khasiat dan Manfaat Kunyit. Jakarta : Agromedika Pustaka 